\title{
An Interview with Stanley Kunitz
}

\author{
Michael Ryan
}

INT.: Your first book of poems, Intellectual Things, was published in 1930. What are your reflections on continuing to write poems seriously for almost $\mathbf{5 0}$ years?

S.K.: I suppose my main feeling is that writing poetry, for me, has been like breathing. It has been the condition of my existence. I've never considered surviving without poetry. The first poems come to you out of nowhere. You don't know that you are a vessel; all you know is that you have poems that have to be written. Later, those early poems seem completely extraordinary because you realize that you were a terribly immature person emotionally. I think most people in their early or mid-twenties are not ready to take the mantle of "poet" over their shoulders and say "I am a poet." It's a little ridiculous to make that assumption at that time in your life-it may be ridiculous at any time. I think of one's feeling for language as a kind of prehensile thing; it must be in the genes. You don't know why you're writing poems, any more than a cat knows why it claws at the bark of a tree, but you're doing it. Because you have to do it. And your intellectual life, such as it is at that stage, is really something separate from your feeling for the language itself. Basically, the young poet has to model himself on the poets whom he loves, preferably not from those who happen to be in fashion at the moment.

INT.: If I remember correctly, the only poet you mention explicitly in any of your poems is Marvell. There is a definite affinity to the metaphysical poets in that first volume. Would you say that was your initial influence?

S.K.: I was mad about the metaphysical poets. During the time when I started writing seriously, I was at Harvard, studying primarily with John Livingston Lowes. In the background were Irving Babbitt, whom I also worked with and who, I thought was an enemy of everything I believed in, and Kittridge, who was the great scholiast of the period. But Lowes was the one who really taught poetry, and his faith was in the Romantic poets, as was mine initially. There wasn't even a course in the metaphysical poets. So I came upon them independently, and they seemed closest to that particular quality of voice and mind that I cared about.

INT.: One thing that strikes me in reading your first volume is your attraction to forms. Wasn't part of Eliot and Pound's influence at the time to break strict form?

S.K.: The poems in Intellectual Things date from 1927, when I was 22. It's true that Eliot came to notice about 1916 or so, and so did Pound, with their first writings, but they had no reputation in the academic or general world. I proposed writing my master's thesis at Harvard on the techniques 
of the Modern writers; the ones I included were Hopkins, Eliot, Cummings, Joyce, Marianne Moore, and, I believe, Proust. When I presented my proposal to the head of the department, Lowes, he looked at me in absolute amazement and said, "You mean you take these people seriously? Don't you know they're only pulling our legs?" That's about where the Modern Movement was then. It's difficult to explain now, but historically the way into the new poetry was through the doorway of the seventeenth century, through the rediscovery of the metaphysical tradition. Tone and technique were the primary agitations.

INT.: Invariably in your first book, the poems adhere to a strict rhyme scheme and metrical pattern, but in many cases the way in which the line is broken tends to conceal that. So the question arises, why use conventional form in order to subsume it?

S.K.: I suppose I believed in an art of limitations, in certain restrictions that the form itself imposes; however, I also believed that if you insisted upon them too strictly, if, for example, you made your rhymes so obvious that there was no escaping them, the result would be an offense to the ear. Basically I've always written according to what my ear told me, and not according to any arbitrary system of metrics or linear conventions. From the beginning, although I was writing in rhyming and metric patterns, I wanted to escape their omnipresence. So the art was one of using the conventions, but trying to move within their limits so that the conventions were not obvious.

INT.: And the limitation, perhaps, forced discoveries?

S.K.: The setting up of a form, whatever the form may be, implies certain limitations. The problem, then, is to be as free as possible within that necessity of your choice. If you don't have boundaries, you are faced with infinity. And my assumption is that art is incapable of dealing with infinity, at least in any formal sense.

INT.: Where, then, does the restriction or limitation come from when you do not write using conventional form, as in many of the poems in your most recent book, The Testing-Tree?

S.K.: I have a music haunting my ear, so that's one limitation; secondly, in writing what may look like free verse I have a system of strong beats in mind. In recent years my line has been getting shorter, partly because I'm cutting down on the adjectives-I'm usually down to two or three stresses to a line. This permits any number of syllables, within reason, as long as the ground pattern is preserved. But the controls are really in the ear itself, and I don't think they should be anywhere else. The ear must tell you if a line is too long, too short, if it lacks a backbone, if it's nerveless, if it has enough promontories, if it has tension of any kind.

INT.: That system of stresses is very apparent in the title poem, "The TestingTree" and "The Customs-Collector's Report" and "River Road," but it's less obvious to me in "Robin Redbreast" and "The Mulch." Maybe the latter two poems are simply less incantatory. 
S.K.: They probably are, but I think that in terms of what I call functional stressing they follow very closely a pattern the ear has determined.

INT.: And that's an intuitive pattern?

S.K.: It is not counted. I write my poems by saying them. It's the only way I know how to write. If it doesn't satisfy my ear then I know it's wrong. So essentially I'm proceeding from the same basis I always did, which is the feeling that poetry has an allegiance to music and another allegiance to dance. The problem for the poet is to both sing and dance, and yet remain within the limits of language.

INT.: A tension arises, does it not, between the impulse toward sound and the impulse toward content?

S.K.: That's the tragic nexus of poetry. The poem wants to be pure sound and it also wants to be straight sense, and it can never be either.

INT.: Because if it's straight sense it's simply discursive prose?

S.K.: So why put it in a poem?

INT.: And if it's pure sound, it's music?

S.K.: And poetry is neither, but yearns in both directions.

INT.: Do you think either impulse could be identified as a primary source for the poem?

S.K.: The word that needs to be introduced in this context is "periodicity." This is what we learn from our immersion in the natural world: its cyclical pattern. The day itself is periodic, from morning through noon to night; so too the stars in their passage, the tides, the seasons, the beat of the heart, women in their courses. This awareness of periodicity is what gives us the sense of a universal pulse. And any art that does not convey that sense is a lesser art. In poetry, it leads us, as Coleridge very definitely saw, toward an organic principle. I suppose that perception by Coleridge is the most profound assertion ever made about the nature of poetry, which I regard as the supreme art. All the other arts, except music as composition, require some matter in order to fulfill themselves. The great thing about poetry is that your selfhood is simultaneously your instrument and your vessel. The words of a poem are like a second skin. They're not apart from the self; they're inwoven with the tissue of the life.

INT.: Language also has a history apart from any individual, which leads to an inexorable fact, for me, that the poem has an existence apart from the poet. It tells him at times what to say. There is always a tension, for me, between self and history, poet and poem.

S.K.: I don't think that's too different from the way your body tells you you're in love, you're growing old, or you're about to die. The language tells you it has certain preordained conditions: it has, for example, syntax; it has vocabulary; it has symbolic meaning. Nobody owns it. When you touch language, you touch the evolution of consciousness and the history of the tribe. You reach for a tool, a common tool, and find to your surprise that it has a cuneiform inscription on the handle.

INT.: I would like to talk more about the development of your work; since 
you've already described some of the changes that have occurred in your poems in terms of form, could you talk about how your concerns or subjects have changed? In the first book, for example, there's an obsession with thought, brain, concept, and the poems are self-reflecting; in the most recent book, the poems are quieter and more involved with the external world. How do you see this development?

S.K.: Naturally my poems reflect my transformations, though I should hope you might detect in them some spirit or principle that persists. My early writing was dense and involuted-so, I guess, was I! Now what I am seeking is a transparency of language and vision. Maybe age itself compels me to embrace the great simplicities, as I struggle to free myself from the knots and complications, the hangups, of my youth. Not that I have forgotten, or want to forget, the rages of my unhappy years-they still seethe inside me. It's true that I am astonished, in my sixties, by the depth of my affection for this life. It's equally true that I am no more reconciled than I ever was to the world's wrongs and the injustice of time.

INT.: You say the rage is still seething. Is that rage important to a poet, to his work?

S.K.: No question of that. A poet needs to keep his wilderness alive inside him. One of the prerequisites for remaining a poet after, let's say, the age of 40 or 50 , is an awareness of the wilderness within oneself that will never be domesticated, never tamed. He must never avert his face completely from the terrors of that dark underworld.

INT.: In the most recent book, you're obviously interested in history as a material for poems; in the first book, the analogous material is myth and theology. Do you see this development as a transference of the same impulse?

S.K.: I don't think it's as clear as your description implies. There are poems in The Testing-Tree that are just as involved with archetypes as anything I've ever done. And the historic materials, as I see them, overrun the foothills of myth.

INT.: Do you see that impulse, if I can so identify your interest in myth and history, as a way out of the ego?

S.K.: Perhaps. The self renews and fortifies itself by falling in love with time. Otherwise it's doomed to repeat itself indefinitely. One hopes to remain open and vulnerable, to keep on being terrified by history.

INT.: Do you think that the activity of writing causes most poets to be monomaniacal, in the sense that it is inherent in the activity itself that one can only write about a limited part of his entire life?

S.K.: Oh yes. In this respect, one of the chains around every poet's neck is his own development as a poet. His beginnings are largely a generational phenomenon, a combination of accidents and influences; thereafter, he builds on that foundation. Maybe at a certain point he would prefer a fresh start, but the difficulty is that he has already established the condition of his art. To change your style you have to change your life. I think almost 
any of the poets we value, if they had lived long enough, might have become their opposites as poets. No single kind of poetry would be sufficient for a millenium.

INT.: You have not been the most prolific poet in the history of literature.

S.K.: God, no.

INT.: That implies a way of working which is perhaps partially not determinable and partially determined. Do you want to talk about that?

S.K.: Sure. I realize that reputations are made by volume as much as by anything else. Most of the big reputations in modern American poetry have been made on the basis of a large body of work. That doesn't happen to be my style. Over a lifetime I've written poems only when I felt I had poems to write. I do not feel apologetic about refusing to convert myself into a machine for producing verse. Sometimes I think that poetry has become a nation of monsters. The anomaly is that, as one of the few survivors of my generation of poets, I'm suddenly threatening to become prolific-for me, that is.

INT.: Do you think it's harder now to have that patience in relationship to the work? Insofar as the university has become the new patron in recent years, the situation for a young poet, or perhaps for any poet, is such that he must publish a book in order to teach. And not just one book, but two books, three books, and four books, sometimes all too quickly. Was the atmosphere more conducive to having that patience 30 or 40 years ago?

S.K.: To answer your question, I'll tell you something of my history. When I was about to recieve my master's degree from Harvard, I assumed that I could stay on as a teaching assistant if I wanted to, not because I was already a poet but because of my scholarship record. As it turned out, I did not stay on; I was told indirectly through the head of the English department that Anglo-Saxons would resent being taught English by a Jew, even by a Jew with a summa cum laude. That shook my world. It seemed to me such a cruel and wanton rejection that I turned away from academic life completely. After I left Harvard, I had no real contact with universities for almost 20 years; I worked on a newspaper, farmed, free-lanced, edited publications.

Then something completely fortuitous happened. In 1945, I was in the Army-my third year-and wretched for various reasons. I was a conscientious objector who had accepted service on the premise that I would not bear arms, but the Army refused to acknowledge the terms of our agreement-a nightmare from beginning to end. Out of nowhere I received a wire from Bennington College offering me a position on the English faculty as soon as I was discharged. Of course I snatched at it. One needs a revolution every few years, and in my circumstances this seemed heavensent. I knew that Roethke was at Bennington, but didn't know that he had been through a violent manic episode-one of his worst. They wanted to ease him out, but he was being difficult about it. Finally, he told them he 
would leave quietly on one condition: hire Kunitz. So that's how I began teaching.

I suppose my personal experience is involved with my feelings about poets in the university. On the whole I think it's stultifying for young poets to leap immediately into the academic life. They would be better off tasting the rigors of a less regulated existence. I was over 40 when I began to teach, and I am grateful now for the difficult years of my preparation. And I still consider myself a free agent, moving from place to place, never accepting tenure. Blake said, "I must create a system myself or be enslaved by another man's." If a poet wants to wait 30 years to publish his next book, he should be given 30 years. What difference does it make in the eye of eternity?

INT.: You published your first poems in magazines such as The Dial and Hound and Horn.

S.K.: That's right.

INT.: How do those magazines compare to those which are published today?

S.K.: One of the nostalgic feelings I have now is for those publications. I remember I had just graduated from college when I sent my first batch of poems to The Dial. Within ten days I received a handwritten letter from Marianne Moore, who was editing The Dial then: it was a very simple little message to this effect: "Dear Mr. Kunitz: I have read your poems, and I do admire them. We shall be so happy to publish them." I felt I had been blessed by the gods. There are no magazines now that are even faintly analogous to The Dial. I don't really care where I publish anymore. Several of the young poets I know have that same feeling of diffidence. There's no publication today that gives them a sense of sanction. A great loss.

INT.: Has the audience for poetry changed since that time?

S.K.: The audience is bigger and, I think, more knowing than it has ever been. That's the paradox. Certainly, it has spun off into scattered little urban cells and colleges; but still, it's there, everywhere you go, a community of friends, waiting, listening. When I was a college student, and for a decade or two thereafter, no contemporary poetry was taught in the universities. Poets were not asked to read, let alone to teach. The underlying assumption was that poetry, after Kipling and Amy Lowell, was not a respectable vocation.

INT.: Can you compare the quality of the poetry itself?

S.K.: It's better now. No comparison. And so much of it! Even morons nowadays seem able to write "accomplished" poems.

INT.: We do seem to have passed the age of literary giants. Do you have an explanation for that?

S.K.: The reason is clear. In one sense, art is inseparable from politics. In hierarchical societies, genius tends to flow to the top-it percolates down on the lesser fry from the towering few who dominate the age. As society becomes more and more democratized, the genius of the race is dispersed 
among larger and larger numbers. A dilution occurs, so that perhaps now there are 20 poets who together are the equivalent of a Milton. There is, however, no Milton.

INT.: Is that unfortunate?

S.K.: I doubt it. Perhaps it's a reversion to primitive societies, where everybody composes songs. Maybe we're inching back to some sort of chorus of poets-no great poets, but still, now and then, great poems.

INT.: The reversion you describe calls to mind McLuhan's notion of the global village. Do you think the popular media have influenced poetry in any way?

S.K.: The popular media, by definition, attract the attention of most of the people most of the time-and, of course, they're easy to take. I see no reason why an oral tradition and a written tradition shouldn't co-existthey've done so for centuries. Historically the former have influenced the latter, as when the ballads entered into the stream of English Romanticism. Right now the contrary is true. Bob Dylan, Leonard Cohen, Rod McKuen, for example, in a descending scale of interest, are byproducts, vulgarizations, of the literary tradition. Compare them with the jazz musicians or the gospel singers, who were authentic expressions of the folk.

INT.: Do you think it's possible to integrate politics and poetry? Some of the poems in your second book, Passport to the War, as the title implies, do have political content. I suppose the most obvious attempt at the integration right now is in the poetry of the women's movement.

S.K.: You cannot separate poets from the society in which they function. The relationship between the poet and his world is an obligatory theme; no poet is granted exemption. He cannot cannibalize himself indefinitely. Even his avoidance of politics is a political gesture. The moot question is one of aesthetic strategies. When the black revolution was at its height, less than a decade ago, the sympathies of most poets, I think, were with the black revolutionaries. And yet the poetry that came out of it was, for the most part, coarse and shapeless and finally unreadable. That, of course, is not to negate the virtue of the cause for which it was written. By the same token, most of the poems overtly incited by the women's liberation movement are diminished by their rant and rhetoric. Yeats was at least partly right when he said that the opposite of poet is the opinionated man-today he would have added "and woman," despite the damage to his prose.

INT.: Akhmatova's poetry has political content, does it not?

S.K.: She's a political poet, but in her work the politics are subsumed in the life. You're hardly aware of the political content of the poems; what moves you is her personal involvement in the issues that make the poem. For example, "Requiem," one of the masterpieces of modern Russian literature, is not a diatribe against the Stalinist terror which blighted her life and took her son from her. What it conveys is a sense of tragic landscape, the 
desolation of hearts in a heartless epoch. Akhmatova learned from Dante the necessity for human scale in depicting the crimes of history.

INT.: How did you become interested in undertaking such a project as translating the poems of Ahkmatova?

S.K.: Through my friendship with Voznesensky I rediscovered my own Russian ancestry, which I had almost forgotten. And suddenly I felt close to Russian poetry, as though I had been waiting to hear it for years. Then I visited Russia in 1967 as part of the Cultural Exchange Program, and I became deeply involved in the lives and fates of her poets. Akhmatova's pure and unaffected voice is the kind of speech I value. I think I can learn from her. That's as good a reason as any for trying to translate her.

INT.: Is the obligation you place on yourself as a translator to make sure that voice comes through? Do you have to choose between a faithfulness to the literal version and the making of a poem in English?

S.K.: That's the crux of the problem-a contradiction of loyalties. On the face of it, there is no resolution. But that doesn't deter you from attempting the impossible.

INT.: I'd like to return for a moment to something we touched upon earlier. I can't imagine how it must have been to begin writing in the literary situation of the Twenties. Were you intimidated by Eliot? Or is his dominance of the poetry of the age a fiction of literary history?

S.K.: It's not a literary fiction at all. To be born in my generation is to have been born in the shadow of the great names who belonged to the previous generation: Eliot, Pound, Frost, Robinson, Stevens, William Carlos Williams, although he was more of a democratic spirit than the others. Living in the country, I had no literary friends, except for Roethke, who visited me occasionally and with whom I corresponded, exchanging manuscripts. It didn't occur to me that the senatorial generation might be interested in what I was doing, and I didn't expect them to be. Today young poets feel perfectly free to converse with their elders, and this is one of the healthiest aspects of the contemporary scene, this conversation going on. But for my generation it was inconceivable that we would even hope for any colloquy with or recognition from our seniors. Nothing happened till I was almost 50 to abate my natural feeling of isolation. But the truth is that I've never gotten over feeling like a loner.

INT.: I'm sure that friendship between you and Roethke was very important to both of you.

S.K.: Both of us needed support and encouragement. For me, Ted was a link to that world of poetry with which I had no other connection. When he came to visit me, he always brought news of other poets. I would hear about those he admired most, the ones he saw, the ones he courted. The interesting aspect of Roethke in his youth was that above all he respected formal excellence, as his early poems indicate. That's where he really learned about the freedoms he could later entertain-from the restraints he practiced in his early work. 
INT.: I'd like to ask you about your method of working in relation to a specific S.K.: poem. Would you read "The Man Upstairs"?

\section{THE MAN UPSTAIRS*}

The old man sick with boyhood fears, Whose thin shanks ride the naked blast, Intones; the gray somnambulist Creaks down interminable stairs, Dreaming my future as his past.

A flower withers in its vase, A print detaches from the wall, Beyond the last electric bill Slow days are crumbling into days Without the unction of farewell.

Tonight there suffers in my street The passion of the silent clerk Whose drowned face cries the windows dark Where once the bone of mercy beat. I turn; I perish into work.

O Magus with the leathern hand, The wasted heart, the trailing star, Time is your madness, which I share, Blowing next winter into mind ... And love herself not there, not there.

INT.: Beautiful. That's a terrific poem.

S.K.: I still like it, too; it's always amazed me that none of the anthologists have ever picked up that one. They are rather incredibly imperceptive about the poems that lie at the core of one's work.

INT.: The whole structure of the poem, its movement, is what makes it powerful for me, but I want to concentrate on one detail of the language: "I perish into work." A naive question, but I hope a purposeful one, how do you come up with that sort of discovery?

S.K.: I have a sense of using the life, of exhausting it in the work itself. The analogue, of course, is the dying image involved with sex. As far as the poet is concerned, life is always dying into art.

INT.: Do you keep a notebook?

S.K.: Yes. I'm always putting down lines, phrases, images, even pasting in clippings, anything that teases my mind. I have stacks and stacks of material that interests and excites me and I keep collecting. There's so much of it, I can never find anything specific-not if I'm looking for it. But if

Acknowledgment is made to Atlantic Monthly Press for permission to reprint. 
I'm leafing through my notebooks, something I jotted down months or years ago often catches my eye. It's been there all the time, sleeping, and at the same time it's been simmering in my own mind. And I look at it and suddenly I can see what else it's hooked to, what other buried phenomena. And at that point, when it signals its attachment to the layers of the life, I can use it.

INT.: When is a poem finished for you?

S.K.: That's a hard question. I really say my poems, as I mentioned earlier. I keep putting down the words as I say them. Usually, after starting a poem in longhand, I type what I have, because I need to get a sense of its look on the page. And then it's a process of building up line after line, discarding the earlier versions and starting again from scratch. Any one poem can involve up to 100 sheets of paper, because it always starts from the beginning and goes as far as it can. When it's blocked, I start all over again and try to gather enough momentum to break through the barrier. That's more or less my method of composition. When there are no more impediments on the page and my original impulse is exhausted, I go to bed. I'm a night-worker.

INT.: How do you teach the writing of poetry?

S.K.: Thoroughly. Passionately. Long ago I discarded theories. The danger of the poet-as-teacher lies in his imposing his persona on his students. I welcome any kind of poet; I don't care if he is my kind or not. Some of the best students I've worked with have turned out to be my own opposites. But that doesn't bother me at all.

INT.: Does your idea of teaching correspond to your interpretation of your position as editor and judge of the Yale Series of Younger Poets?

S.K.: I think it does. My obligation there, first of all, is to read everything that is submitted; secondly, to be as open and fair and objective as I can. I don't look for any specific kind of poet when I read those manuscripts; I'm looking for a poet. Let me add that nobody has an inside track. All but one of the poets I've picked have been perfect strangers.

INT.: Your selected prose will be published by Atlantic Monthly Press next spring-essays and conversations. Why now?

S.K.: Maybe it's time for me to find out whether all the stuff I've turned out on poetry and art and politics makes any sense when put together.

INT.: Here's a valedictory question: can you talk briefly about the direction your own poetry is taking now?

S.K.: It's fairly clear to me that I'm moving toward a more expansive universe. I propose to take more risks than I ever did. Thank God I don't have to ask anyone else's permission to do what I want to do. If I give it my imprimatur, it's OK. That's the privilege and insolence of age.

This interview was conducted in Mr. Kunitz's home in New York City on January 10, 1974 . 